\title{
Analisis Wacana Kritis Film Rudy Habibie dalam Meningkatkan Kemampuan Berpikir Kritis Mahasiswa
}

\author{
Goziyah \\ Universitas Muhammadiyah Tangerang \\ Corresponding email: goziyah1812@gmail.com
}

\begin{abstract}
Discourse analysis has been noticed by several language researchers and educators over the past two decades. This study aims to analyze the use of discourse analysis on film as a medium of learning in improving students' critical thinking skills, especially in learning discourse analysis. Rudy Habibie film is used as a medium for this analysis. The conceptual framework framework for Fairclough was adopted in this study, with a focus on analyzing meso-level critical discourse. This study explores how discursively formed in the process of production, distribution, and consumption in the film Rudy Habibie. This finding illustrates various behaviors taken from the Rudy Habibie film which aims to express stereotypes, prejudices, hegemony, power, and ideological attitudes. The ideology presented leads the audience through the film's story as a result of text production, distribution, and consumption. Representation contributes to building social strength. Furthermore, this research is believed to have implications for language teaching, especially in discourse analysis. The application of a critical discourse analysis approach in learning makes students able to understand the writer, find meaning and reason about certain writing styles and to enhance their critical thinking.
\end{abstract}

Keywords: analysis of critical discourse, film, critical thinking skills, students

\begin{abstract}
Abstrak
Analisis wacana telah diperhatikan oleh beberapa peneliti bahasa dan pendidik selama dua dekade terakhir. Penelitian ini bertujuan menganalisis penggunaan analisis wacana pada film sebagai media pembelajaran dalam meningkatkan kemampuan berpikir kritis mahasiswa, khususnya dalam pembelajaran analisis wacana. Film Rudy Habibie digunakan sebagai media untuk analisis ini. Konsep kerangka teori Fairclough diadopsi dalam penelitian ini, dengan fokus pada analisis wacana kritis tingkat meso. Penelitian ini mengeksplorasi bagaimana diskursif terbentuk dalam proses produksi, distribusi, dan konsumsi pada film Rudy Habibie. Temuan ini menggambarkan berbagai perilaku yang diambil dari film Rudy Habibie yang bertujuan untuk mengungkapkan stereotip, prasangka, hegemoni, kekuasaan, dan sikap ideologis. Ideologi yang disajikan mengantarkan penonton melalui kisah film sebagai hasil produksi teks, distribusi, dan konsumsi. Representasi berkontribusi pada pembangunan kekuatan sosial. Lebih lanjut, penelitian ini diyakini memiliki implikasi untuk pengajaran bahasa, terutama dalam analisis wacana. Penerapan pendekatan analisis wacana kritis dalam pembelajaran, membuat mahasiswa dapat memahami penulis,
\end{abstract}


menemukan makna dan alasan tentang gaya penulisan tertentu serta untuk meningkatkan pemikiran kritis mereka.

Kata Kunci: analisis wacana kritis, film, kemampuan berpikir kritis, mahasiswa

\section{PENDAHULUAN}

Wacana dapat dilihat sebagai seperangkat makna, metafora, representasi, gambar, cerita, laporan dan sebagainya yang dalam beberapa cara menghasilkan versi tertentu dari peristiwa bersama (Baker \& Ellece, 2011). Salah satu ciri wacana diungkapkan oleh Chen (2016) \& S.Eva. (2015) bahwa itu berbentuk sosial dan konstitutif sosial. Setiap peristiwa diskursif dilihat sebagai sebuah teks, seperti praktik diskursif, dan praktik sosial (Fairclough, 1992). Mungkin ada berbagai wacana yang berbeda dengan cerita yang berbeda tentang suatu hal dan cara memahaminya.

Pada pendekatan kualitatif, analisis wacana kritis menggambarkan, menafsirkan, dan menjelaskan secara kritis tentang pembentukan wacana sampai pada ketidakseimbangan sosial yang ada dalam wacana tersebut. Analisis wacana kritis mempelajari kekuatan sosial dalam konteks sosial, termasuk politik melalui makna semantik dari wacana. Analisis wacana kritis melihat unsur linguistik dan diskursif dari hubungan sosial kekuasaan dalam masyarakat kontemporer. Dalam mendefinisikan analisis wacana kritis, Fairclough (1995) menyebutkan tiga konstruksi utama, (1) dimensi tekstual, ini berkaitan dengan linguistik, misalnya dengan melihat kosa kata, semantik, dan kalimat, kohesi, koherensi, dan diksi; (2) dimensi kewacanaan, berkaitan dengan proses produksi, distribusi sampai konsumsi teks; dan (3) dimensi praktik sosial budaya, dimensi ini berkaitan dengan konteks di luar teks, seperti situasi, institusi, dan soaial budaya. Analisis wacana kritis memberikan teori dan metode yang dapat digunakan untuk melakukan studi empiris tentang hubungan antara wacana dan sosial, termasuk pengembangan budaya di berbagai domain sosial. Tujuan analisis wacana kritis adalah untuk menjelaskan dimensi linguistik dari fenomena sosial dan budaya dan proses perubahan dalam modernitas (Jorgensen \& Phillips, 2007:15).

Artikel ini bertujuan untuk menganalisis penggunaan analisis wacana film sebagai media pembelajaran dalam meningkatkan pemikiran kritis siswa, khususnya dalam pembelajaran analisis wacana. Sebuah film Indonesia berjudul Rudy Habibie digunakan sebagai media untuk analisis wacana kritis khususnya pada tataran praktik diskursus. Praktik diskursif membutuhkan interpretasi proses diskursif yang mencakup aspek produksi, distribusi, dan konsumsi teks. Pada tahap produksi, analisis mendalam dilakukan untuk seluruh pihak yang terlibat, mengetahui cara-cara dalam memproduksi teks. Pada tahap distribusi teks, media yang digunakan dianalisis untuk menggambarkan bagaimana proses mendistribusikan teks, baik melalui media cetak atau elektronik. Ini harus diperiksa untuk mengetahui dampak pada efek wacana karena setiap media memiliki kelebihan dan kekurangan yang berbeda. Pada tahap konsumsi teks, penerima teks yang ditargetkan dianalisis untuk mengetahui siapa yang mengonsumsi media karena setiap media memiliki pangsa pasar yang berbeda.

Dalam analisis wacana kritis, konteks bahasa dapat dilihat sebagai alat yang digunakan untuk tujuan dan praktik tertentu termasuk praktik dan kekuasaan ideologis (Noermanzah, dkk. 2018). Ini dapat dilihat sebagai konsep sentral dari analisis wacana kritis. Raymond William dalam Fiske (1990) menggambarkan ideologi dalam 3 domain; 1) sistem kepercayaan oleh kelompok atau kelas tertentu. 
Definisi ini digunakan dalam bidang psikologi yang memandang psikologi sebagai suatu sikap yang terbentuk dan terorganisir secara koheren; 2) sistem kepercayaan yang dibuat yang bisa dilawan dengan pengetahuan. Dalam pengertian ini, ideologi adalah kategori yang diciptakan dan kesadaran palsu ketika kelompok dominan menggunakannya untuk mendominasi kelompok non-dominan lainnya; 3) proses umum makna dan produksi ide. Teks mencerminkan ideologi melalui bahasa dan dapat mempengaruhi cara orang berpikir. Wacana bisa dilihat sebagai media untuk membujuk orang. Chen (2016) menyatakan dalam temuan penelitiannya bahwa perbedaan linguistik yang melibatkan bidang-bidang seperti klasifikasi leksikal, jenis proses, dan representasi wacana dapat ditelusuri kembali ke orientasi ideologis pribadi. Itu tidak dapat dijelaskan tanpa mempertimbangkan berbagai orientasi ideologis dan hubungan kekuasaan. Pada dasarnya, bahasa dibentuk oleh kekuatan dan ideologi. Ideologi berada dalam wacana. Ideologi dan kekuasaan pada dasarnya bersifat diskursif. Ideologi terutama didirikan, dipertahankan dan ditantang.

Wacana tidak hanya mencakup bahasa tertulis dan lisan, tetapi termasuk gambar visual (Jorgensen \& Phillips, 2007). Dimungkinkan untuk diterapkan dengan mempertimbangkan karakteristik khusus semiotik visual dan hubungan antara bahasa dan gambar. Sebagai salah satu gambar visual, film dapat dilihat sebagai produk budaya manusia yang mewakili nilai-nilai pandangan kelompok orang tertentu, termasuk semangat dan ideologi mereka. Sebagai karya seni budaya dan sinematografi yang dapat diperagakan dengan atau tanpa suara. Trianton (2013) menyatakan bahwa film adalah media komunikasi massa yang membawa pesanpesan berisi ide-ide penting yang disampaikan kepada publik dalam bentuk tontonan. Film dapat digambarkan sebagai gambar hidup yang berisi cerita. Murti (2018) menyatakan bahwa film adalah pengalaman dalam bentuk non-verbal seperti fotografi termasuk bentuk pernyataan tanpa sintaksis. Sebagai media, film tentu saja mewakili pandangan yang dipegang oleh kelompok tertentu, termasuk ideologi dan gagasan yang dibawa oleh kelompok tersebut. Ini menjadi sangat penting, karena film tersebut menyampaikan ideologi secara halus dan memiliki unsur paksaan.

Rudy Habibie adalah film drama Indonesia tentang kisah pemuda visioner: Rudy Habibie sebelum ia dikenal sebagai teknokrat dan presiden Republik Indonesia ke-3, B.J. Habibie. Film ini mendapat respons positif dari publik dan ditunjukkan oleh posisinya pada tiga daftar film terlaris di Indonesia tahun 2016 dengan dua juta penonton. Pada tahun 2016, film Rudy Habibibie mendapat beberapa penghargaan di festival film Bandung untuk, (1) penghargaan kategori film terpuji; (2) penghargaan aktris yang dipuji oleh Chelsea Islan; dan (3) penghargaan aktris yang didukung oleh Indah Permatasari. Sebagai media, film ini dimaksudkan untuk menyampaikan ideologi yang dapat mempengaruhi penonton melalui bahasa tertulis dan lisan termasuk gambar visual. Media dapat dilihat sebagai alat untuk menyampaikan ideologi (Zhang, dkk. 2014). Pada akhirnya, temuan penelitian ini dapat digunakan sebagai alternatif media pengajaran yang menarik dalam pembelajaran wacana.

\section{METODE}

Metode penelitian menggunakan metode analisis wacana kritis. Sumber data utama dalam penelitian ini, yaitu film Rudy Habibie. Analisis wacana kritis mencoba menghubungkan unsur mikro, meso, dan makro pada dimensi: (a) teks, (b) praktik wacana, dan (b) praktik sosial budaya (Noermanzah, 2017). Dalam penelitian ini dibatasi hanya pada aspek meso. Data sekunder diperoleh dari tinjauan literatur, 
seperti artikel jurnal dan beberapa teori yang relevan, untuk memperkuat pemahaman analisis wacana kritis, praktik diskursif, dan media film. Teknik pengumpulan data menggunakan teknik dokumentasi. Teknik analisis data dalam analisis wacana kritis ini dibatasi pada tingkat meso. Penelitian ini mengeksplorasi bagaimana diskursif terbentuk dalam proses produksi, distribusi, dan konsumsi pada film Rudy Habibie. Temuan ini menggambarkan berbagai perilaku yang diambil dari film Rudy Habibie yang bertujuan untuk mengungkapkan stereotip, prasangka, hegemoni, kekuasaan, dan sikap ideologis. Uji keabsahan data dengan cara membercheck dan validitas pakar.

\section{HASIL}

Film Rudy Habibie, sebuah prekuel dari film Habibie \& Ainun, diproduksi oleh Manoj Punjabi dari MD Entertainment. MD Entertainment dikenal sebagai salah satu rumah produksi terbesar di Indonesia yang memiliki citra baik dalam membuat banyak film yang sukses dan berkualitas. Itu bisa dilihat dari berbagai penghargaan yang diraih. Tidak hanya soal kualitas, mereka tahu bagaimana membuat film terlaris.

Manoj sebagai seorang produser memiliki kepercayaan diri bahwa film Rudy Habibie akan sukses seperti yang sebelumnya, Habibie \& Ainun. la menyadari dan percaya bahwa Habibie adalah sosok yang menginspirasi yang dapat menarik banyak penonton. Itu diperkuat dengan tanggal pemutaran film yang bertepatan dengan BJ. Ulang tahun Habibie yang ke-80 pada 25 Juni 2016 . Tidak hanya tentang sosok Habibie, sebagai seorang produser dan orang kunci, Manoj akhirnya mengerti apa yang harus ia lakukan untuk menciptakan keinginannya. Manoj memilih orangorang hebat di bidang film untuk terlibat dalam memproduksi film ini. Hanung Bramantyo terpilih untuk mengarahkan film ini. Orang-orang tahu dan percaya kualitasnya dalam menyutradarai film. Manoj merupakan salah satu sutradara film Indonesia terbaik yang meraih banyak penghargaan dari pembuatan filmnya. Hanung dikenal memiliki idealisme dalam melakukan pekerjaannya. Hanung membantahnya Film Rudy Habibie adalah produk yang berorientasi bisnis. Mereka memproduksi film dengan mempertimbangkan hal-hal yang dapat menarik orang untuk menonton, seperti kisah percintaan antara Rudy dan wanita Polandia, Ilona, dalam bahasa Jerman. Hanung menyadari bahwa kekurangan film ini tidak diperlihatkan sosok Ainun, pada kenyataannya, film ini adalah prekuel dari film sebelumnya, Habibie \& Ainun.

Manoj tidak hanya menjadi sutradara film, bersama dengan Gina S. Noer, Hanung menyiapkan naskah film Rudy Habibie. Naskah diadaptasi dari novel yang ditulis oleh Gina, Rudy: Kisah Masa Muda Sang Visioner, dan Hanung mengembangkan cerita dengan mempertimbangkan permintaan pasar. Film ini fiksi tetapi dengan latar belakang sejarah. Itu dibuat hanya "berdasarkan kisah nyata yang menginspirasi" dan bukan "kisah nyata". Beberapa adegan tampak berlebihan dan terlalu didramatisir. Selain itu, soundtrack asli, Mencari Cinta Sejati oleh Cakra Khan, memperkuat rasa romantis dari cerita tersebut. Pradeep (2016) menyatakan bahwa lagu-lagu tersebut adalah domain lain dari melakukan analisis wacana kritis, hal tersebut membawa banyak aspek kehidupan sehari-hari yang sangat kompleks dalam kaitannya dengan proses pembuatan makna. Melly Goeslaw dan Anto Hoed sebagai penulis lagu menyatakan bahwa tidak mudah untuk membuat lagu karena mereka mencoba mengomposisi lagu untuk dirasakan sebagai Habibie muda dalam 
menemukan cinta sejatinya. Lagu itu lebih istimewa karena proses mastering dilakukan oleh Marks Sherry di Outburst Studio, Skotlandia.

Dalam proses pembuatan film, Manoj berusaha memaksimalkan semuanya. Untuk mendapatkan kualitas suara film, pencampuran suara dilakukan di Hollywood dengan Christopher Sinclair David, desainer suara The Expendables, Olympus Has Fallen, Face Off, Alien 3, Pie Amerika yang telah menerima nominasi Oscar untuk film tersebut Legend of The Fall (Zwick, 1994). Setiap adegan dalam film ini memiliki jiwa yang dalam dan mendebarkan.

Para aktor dan aktris yang terlibat dalam film Rudy Habibie dipilih dengan tidak hanya mempertimbangkan kualitas, tetapi juga dengan mempertimbangkan ketertarikan penonton. Reza Rahadian dipercaya sebagai sosok yang tepat sebagai tokoh utama film ini. la dianggap berhasil memerankan sosok Habibie. Keterlibatan Chelsea Islan memperkuat daya tarik film. Sebagai aktris muda, ia memiliki kualitas bintang yang sangat baik yang tidak hanya berasal dari penampilan dan perilakunya, tetapi juga dari pengalamannya bermain teater. Hal lain yang menarik dalam film ini adalah keterlibatan tiga komik Indonesia terkenal, Ernest Prakarsa, Boris Bokir, dan Pandji Pragiwaksono. Hanung mencoba menampilkan sisi komedi film, tetapi dalam film ini ia menantang mereka untuk berakting dalam film biografi atau film biografi. Para pemain lainnya memperkuat film ini melalui masing-masing karakter, termasuk Dian Nitami dan Dony Damara yang memiliki banyak pengalaman dan prestasi dalam bisnis film.

Pembuat film memberikan gambar visual yang menarik dengan komposisi pengaturan, koreografi serta mode Eropa yang digunakan oleh para pemeran, terutama llona. Selain pengaturan lokasi, komposisi, dan sudut pengambilan gambar, properti ini mampu membawa suasana ke masa lalu dengan pengaturan di Jerman. Delapan puluh persen pengaturan film diambil di Jerman langsung dengan kru film lokal dan sisanya diambil di Indonesia. Pengaturan setiap adegan dalam film ini selesai. Para kameramen dan direktur seni berhasil menggambarkan sifat desa, perang, nilai-nilai keluarga, suasana sosial, termasuk lanskap Jerman lengkap dengan geografi yang berbeda, kehidupan sosial, profesionalisme kerja, perjuangan melawan tantangan, kehidupan pendidikan, romansa, gerakan siswa di Eropa dan keragaman dalam kerangka nasionalisme untuk saling toleransi dalam menghormati ibadah.

Pada tahap distribusi teks, data menunjukkan bahwa MD Pictures memiliki strategi dan komitmen yang baik dengan mengalokasikan anggaran promosi sekitar empat hingga lima belas miliar rupiah. Manoj menyatakan bahwa enam puluh persen dari anggaran mengalokasikan promosi asli dan empat puluh persen di konvensional. Dia percaya bahwa promosi harus dilakukan dengan cara yang cerdas melalui berbagai media (televisi, koran, majalah, radio, twitter, instagram, saluran youtube, facebook dan poster). Salah satu surat kabar nasional Jerman, Sachsische Zeitung, membawa berita tentang film Rudy Habibie. Untuk mendukung distribusi, banyak program telah dirancang dengan menarik seperti talkshow, trailer termasuk meet and greet. Ketika film premier, para produser mengundang banyak pejabat negara untuk menonton bersama dan meminta mereka untuk memberikan testimonial terkait film Rudy Habibie. Presiden Indonesia, Jokowi, bersama dengan wakil presiden, Jusuf Kalla, dan para menteri menghadiri pemutaran perdana, termasuk Presiden Indonesia ke-6, Susilo Bambang Yudhoyono.

Film sebagai media dalam praktik diskursif memiliki target audiens sebagai konsumen produk. Data menunjukkan kepada kita bahwa dua juta orang telah 
menonton film Rudy Habibie, meskipun Manoj, sebagai produser, memiliki ambisi untuk film Rudy Habibie untuk ditonton oleh 10 juta orang. Bahkan, Rudy Habibie sang moviewas berada di posisi ketiga film terlaris tahun 2016. Selain di Indonesia, film itu pernah diputar di Malaysia.

Temuan di atas menggambarkan praktik diskursif yang diambil dari film Rudy Habibie sebagai media. Media adalah domain yang eksplisit dan publik terpapar pada berbagai ideologi yang memengaruhi dan menutup-nutupi pikiran mereka ketika ideologi tertentu diberlakukan pada mereka dalam kehidupan sehari-hari (Ramanathan \& Hoon, 2015). Film dapat dilihat sebagai teks. Fairclough (1992) memperkuat dengan menggambarkan bahwa setiap peristiwa diskursif dilihat sebagai serentak sepotong teks, contoh praktik diskursif, dan contoh praktik sosial. Tiga dimensi praktik diskursif meliputi produksi, distribusi, dan konsumsi yang diambil dari Rudy Habibie, film yang menghasilkan ideologi.

Data menunjukkan bahwa pembuat film mengusulkan ideologi melalui film Rudy Habibie, tidak hanya tentang cerita tetapi juga melalui proses produksi, cara mereka mendistribusikan teks dan konsumsi penonton. Pembuat film dapat dilihat sebagai kelompok dominan yang mencoba mempengaruhi kelompok yang tidak dominan. Mahboob \& Paltridge (2013) menyatakan bahwa sangat penting untuk memeriksa berlakunya kekuasaan dan memahami cara-cara di mana kekuasaan dilakukan oleh kelompok dominasi pada yang tertindas. Pembuat film Rudy Habibie berusaha membuat orang percaya bahwa mereka harus menonton film karena kualitas yang dihasilkan oleh tim yang berkualitas. Untuk mencapai tujuan itu, propaganda apa pun sebagai bagian dari tahap distribusi telah dilakukan melalui berbagai media. Media yang digunakan mencerminkan target audiens. Manoj benarbenar ahli dalam mengoptimalkan penggunaan media.

Keterlibatan banyak aktor yang baik, tim yang baik dan banyak pejabat negara sebagai orang-orang penting di negara ini menjadi kekuatan dalam mendistribusikan film ini sebagai produk, dan Manoj benar-benar mengerti tentang itu. Sosok Reza Rahadian dan Chelsea Islan adalah daya tarik film tersebut. Selain itu, kesaksian dari banyak orang penting seperti Jokowi, Jusuf Kalla, Susilo Bambang Yudhoyono, memperkuat distribusi film. Pengaruh orang-orang itu membuat penonton percaya tentang kualitas film. Sosok Habibie menjadi citra merek film tersebut. Kisah yang menggambarkan sosok Rudy sebagai orang yang jenius, gigih, bergairah, dan optimis.

Melalui film ini, sang produser dianggap sukses dalam membuat film ini untuk ditonton oleh semua umur dan menjadi film yang terinspirasi. Sebagai akibatnya, film ini menjadi film terlaris di tahun 2016 sebagai prediksi produser. Ideologi yang disajikan mengantarkan penonton melalui kisah film sebagai hasil produksi teks, distribusi, dan konsumsi.

Penelitian ini diyakini memiliki implikasi untuk pengajaran bahasa, terutama dalam mata pelajaran wacana. Penerapan pendekatan analisis wacana kritis dalam pembelajaran, siswa harus dapat mencapai pemahaman gaya penulis, menemukan makna dan alasan untuk pilihan gaya tertentu (Lawson, 2008). Clark \& Ivanic (1999) memperkuat dengan menyatakan bahwa pengenalan analisis wacana kritis dalam kelas akan mendorong perkembangan kesadaran bahasa, memberikan siswa lebih banyak kontrol atas penggunaan bahasa mereka sendiri, serta pemahaman yang lebih besar tentang bagaimana mereka tercermin dalam bahasa, penggunaan bahasa kepada orang lain. Lawson (2008) menambahkan dengan menyatakan bahwa analisis wacana kritis juga memiliki nilai dalam mendorong siswa untuk 
Analisis Wacana Kritis Film Rudy Habibie dalam Meningkatkan Kemampuan Berpikir Kritis ...

menantang teks dalam bahasa ibu mereka. Sejalan dengan pernyataan tersebut, peneliti menyarankan kepada guru atau dosen untuk dapat menemukan materi wacana atau media yang sesuai dengan tujuan pembelajaran dan karakteristik siswa atau mahasiswa.

\section{PEMBAHASAN}

Berdasarkan penggunaan analisis wacana pada film dapat meningkatkan keterampilan berpikir kritis siswa atau mahasiswa. Secule, Herron, \& Tomasello (1992) mejelaskan bahwa kelebihan penggunaan film dalam pembelajaran adalah memungkinkan siswa untuk menyaksikan dinamika interaksi ketika mereka mengamati nilai-nilai dalam yang ada dalam film tersebut melalui percakapan, dialogdialog, dan isyarat seperti gerakan yang ada dalam film tersebut. Penggunaan film memungkinkan peserta didik untuk mendapatkan wawasan tentang interaksi dinamis dari penutur dengan wacana otentik. Selain itu, beberapa manfaat belajar analisis wacana melalui film, seperti memahami wacana dan meningkatkan keterampilan berpikir kritis mereka (Coniam, 2001), telah menunjukkan efek yang baik dari menggunakan film untuk melibatkan peserta didik dalam situasi kehidupan nyata untuk meningkatkan wacana kritis mereka, kemampuan, serta keterampilan berpikir kritis mereka.

Sehubungan dengan fungsi presentasi multimedia dalam sebuah film, Simonson, dkk. (2014) menjelaskan empat tahap kunci keberhasilan dalam pembelajaran khususnya dalam proses pemilihan teknologi yang tepat, yaitu (1) menguji teknologi pembelajaran yang tepat, (2) menentukan hasil pembelajaran (kompetensi yang ingin dicapai), (3) mengidentifikasi pengalaman belajar dan menyesuaikannya dengan teknologi yang tersedia, dan (4) menyiapkan pengalaman belajar yang akan disajikan. Keempat tahap tersebut dapat berfungsi sebagai referensi bagi guru atau dosen untuk memberikan materi yang tepat dengan kegiatan yang bermakna bagi siswa. Teknologi instruksional harus mendukung proses pembelajaran siswa sehingga mereka memahami materi secara optimal. Selanjutnya, jika teknologinya tersedia, tetapi tanpa tujuan atau kompetensi yang jelas, proses pembelajaran tidak akan berhasil. Guru atau dosen harus merujuk pada hasil utama atau kompetensi yang harus dicapai siswa. Kegiatan belajar yang ditawarkan juga harus dapat diakses dan diterima. Pemilihan bahan atau kegiatan pembelajaran harus mempertimbangkan apakah sumber daya itu mudah dijangkau dan diterima oleh siswa sebagai pengalaman belajar yang bermakna.

\section{KESIMPULAN DAN SARAN}

Hasil penelitian ini telah membuktikan bahwa analisis wacana kritis dapat digunakan untuk mengetahui hubungan antara bahasa dan ideologi dalam film Rudy Habibie sehingga dapat dijadikan media pembelajaran dalam meningkatkan kemampuan berpikir kritis mahasiswa terutama dalam pembelajaran analisis wacana. Dalam film Rudy Habibie dapat diungkap tetang hegemoni, kekuatan, dan ideologi. Temuan ini diharapkan dapat berkontribusi pada pengetahuan yang ada tentang penelitian analisis wacana kritis untuk meningkatkan kesadaran di antara para peneliti tentang film yang ingin melakukan studi analisis wacana kritis. Selain itu, temuan penelitian dapat dipertimbangkan oleh guru dan dosen untuk digunakan sebagai media pembelajaran wacana. 


\section{DAFTAR PUSTAKA}

Baker, P. \& Ellece, S. (2011). Key Terms in Discourse Analysis. London: Continuum International Publishing Grup.

Chen, Y. (2016). A Critical Discourse Analysis of News Reports on Sino-Japan Boat Collision. International Conference on Education \& Educational Research and Environmental Studies (EERES). ISBN: 978-1-60595-393-9

Clark, R. \& Ivanič, R. (1999). Raising Critical Awareness of Language: A Curriculum Aim for the New Millenium. Language Awareness, 8(2), pp. 63-70.

Coniam, D. (2001). The Use of Audio or Video Comprehension as an Assessment Instrument in the Certification of English Language Teachers: A Case Study. System Journal, 29 (1): 1 -14.

S, Eva. (2015). Analisis Jender Wacana Materi Pelajaran Buku Teks Bahasa Indonesia di SD Kelas Tinggi Bengkulu Selatan. Diksa: Pendidikan Bahasa dan Sastra Indonesia, 1(1), 1-10. doi:10.33369/diksa.v1i1.3130

Fairclough, N. (1992). Discourse and Socialchange. Cambridge: Polity Press.

Fairclough, N. (1995). Critical Discourse Analysis: The Critical Research of Language. New York: Longman Grup Limited.

Fiske, J. (1990). Introduction to Communication Studies. Second Edition.London: Routledge.

Jorgensen, M. W. \& Phillips, L. J. (2007). Analisis Wacana Teori dan Metode. Yogyakarta: Pustaka Pelajar.

Lawson, A. J. (2008). One-on-one with Obama: An Analysis. Centre for English Language Studies. The University of Birmingham.

Mahboob, A. \& Paltridge, B. (2013). Critical Discourse Analysis and Critical Applied Linguistics. Theencyclopedia of applied linguistics. UK: Wiley Blackwell.

Murti, S., Nisai Muslihah, N., \& Permata Sari, I. (2018). Tindak Tutur Ekspresif dalam Film Kehormatan di Balik Kerudung Sutradara Tya Subiakto Satrio. Silampari Bisa: Jurnal Penelitian Pendidikan Bahasa Indonesia, Daerah, dan Asing, 1(1), 17-32. doi:10.31540/silamparibisa.v1i1.7

Noermanzah, N., Emzir, E., \& Lustyantie, N. (2017). Variety of Rhetorics in Political Speech President of the Republic of Indonesia Susilo Bambang Yudhoyono and Joko Widodo in Educational Field. Humanus, 16(2), 221. doi:10.24036/humanus.v16i2.8103 
Analisis Wacana Kritis Film Rudy Habibie dalam Meningkatkan Kemampuan Berpikir Kritis ...

Noermanzah, Emzir, \& Lustyantie, N. (2018). President Joko Widodo's Rhetorical Technique of Arguing in the Presidential Speeches of the Reform Era. International Journal of Applied Linguistics and English Literature, 7(5), 117. doi:10.7575/aiac.ijalel.v.7n.5p.117

Pradeep, K. (2016). Analysing Tamil Films with Critical Discourse Analysis Approach. International Journal of Linguistics and Computational Applications (IJLCA), 3(3). ISSN 2394-6385 (Print) ISSN 2394-6393 (Online)

Ramanathan, R. \& Hoon, T. B. (2015). Application of Critical Discourse in Media Discourse Studies. 3L: The Southeast Asian Journal of English Language Studies, 21(2), $57-68$.

Trianton, T. (2013). Film sebagai Media Belajar. Yogyakarta: Graha Ilmu.

Secule, T., Herron, C. \& Tomasello, M.. (1992). The Effect of Video Context on Foreign Language Learning. Modern Language Journal, 76 (4), pp. 480-490. DOI: https://doi.org/10.1111/j.1540-4781.1992.tb05396.x

Simonson, M., Smaldino, S. \& Svacek, S. M.. (2014). Teaching and Learning at a Distance: Foundations of Distance Education (6th Ed). Boston: Pearson Education, Inc.

Zhang, M. (2014). A Critical Discourse Analysis of Political News Report. Theory and practice in language studies, 4(11), 2273-2277. Retrieved from http:www.ojs.academypublisher.com/

Zwick, E. (1994). Legends of the Fall. Box Office Mojo. Diakses tanggal 2018-10-23. 